Jurnal Keperawatan Silampari

Volume 1, Nomor 2, Juni 2018

e-ISSN : 2581-1975

p-ISSN : 2597-7482

DOI: https://doi.org/10.31539/jks.v1i2.82

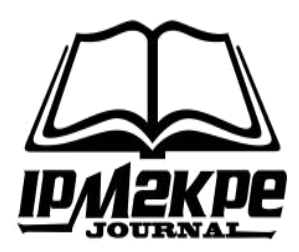

\title{
PENGALAMAN IBU DALAM MERAWAT BAYI PRETERM YANG PERNAH DIRAWAT DI RUANG NEONATUS INTENSIVE CARE UNIT (NICU)
}

\author{
Padila $^{1}$, Muhammad Amin ${ }^{2}$, Rizki $^{3}$ \\ Program Studi Ilmu Keperawatan, Universitas Muhammadiyah Bengkulu ${ }^{1,3}$ \\ Program Studi Kesehatan Masyarakat, Universitas Muhammadiyah Bengkulu² \\ padila_ahmad@yahoo.co.id ${ }^{1}$
}

\begin{abstract}
ABSTRAK
Tujuan penelitian ini untuk mengeksplorasi pengalaman ibu dalam merawat bayi preterm yang pernah dirawat di ruang NICU Kota Bengkulu. Jenis penelitian yang digunakan adalah penelitian kualitatif dengan pendekatan fenomenologi. Hasil penelitian terdapat 6 enam) tema yang dihasilkan, yaitu gambaran ibu tentang bayi yang lahir preterm dan karakteristiknya, etiologi atau penyebab preterm, pengalaman ibu perawatan bayi preterm setelah pulang dari RS, dukungan yang diperoleh ibu semasa perawatan bayi preterm, mekanisme koping ibu dalam merawat bayi preterm, dan reaksi ibu selama merawat bayinya yang preterm. Simpulan penelitian ini adalah pengalaman ibu dalam merawat bayi preterm yang pernah dirawat di ruang NICU Kota Bengkulu.
\end{abstract}

Kata Kunci : Fenomenologi, Pengalaman Ibu, Preterm

\begin{abstract}
The purpose of this study was to explore the experience of mothers in caring for preterm babies who had been treated in the NICU room in Bengkulu City. This type of research is a qualitative research with a phenomenological approach. The results of the study were 6 (six) themes produced, namely the description of mothers about babies born preterm and their characteristics, etiology or causes of preterm, the experience of preterm baby care after returning from hospital, support obtained by mothers during the care of preterm infants, maternal coping mechanisms in caring for a preterm baby, and the mother's reaction while caring for her preterm baby. The conclusion of this study is the mother's experience in caring for preterm babies who have been treated in the NICU room in Bengkulu City.
\end{abstract}

Keywords: Phenomenology, Mother's Experience, Preterm 


\section{PENDAHULUAN}

World Health Organization (WHO) menyatakan Preterm atau Berat Badan Lahir Rendah (BBLR) merupakan neonatus yang terlahir dengan berat badan kurang dari 2500 gram. Saat ini BBLR masih selalu menjadi masalah kesehatan masyarakat yang secara global dapat berdampak baik pada jangka pendek maupun panjang terhadap masalah kesehatan (WHO, 2014). di tahun 2011, terdapat $15 \%$ bayi dilahirkan dalam kondisi preterm secara globalisasi, hal ini berarti lebih kurang dari 20 juta jiwa, terlahir dengan BBLR. Kelahiran dengan BBLR yang terbanyak sebagian besar dilahirkan di negara berkembang termasuk Indonesia, terutama di daerah yang populasinya rentan dan beresiko (WHO, 2014). BBLR tidak hanya menjadi penyebab utama mortalitas prenatal dan penyebab morbiditas. Berdasarkan hasil penelitian terbaru yang menemukan bahwa jika dalam penatalaksanaan bayi dengan BBLR tidak teratasi dengan benar maka juga dapat meningkatkan resiko untuk beberapa penyakit yang tidak menular seperti diabetes dan kardiovaskuler di kemudian hari (WHO, 2014).

Angka kematian bayi (AKD) merupakan salah satu indikator yang menentukan kualitas bagi kesehatan masyarakat di suatu negara. Berdasarkan data dari SDKI pada tahun 2014-2015, angka kematian bayi di Indonesia masih tergolong dalammkategori tinggi yaitu 35 per 1000 kelahiran hidup. Dewasa ini penyebab utama terjadinya kematian bayi antara lain adalah bayi terlahir preterm atau dengan BBLR dengan hasil frekwensi kejadiannya sekitar 29\%. Terkait hal tersebut, target Rencana Pembangunan Jangka Menengah Nasional (RPJMN) yang salah satunya adalah menurunkan angka kematian pada bayi preterm di angka 26 per 1000 kelahiran neonatus yang hidup (Depkes RI, 2016). Hal ini selaras dengan hasil temuan menurut Balitbangkes, Kemenkes RI, (2013) yang menyatakan Indonesia sendiri persentase BBLR tahun 2013 mencapai 10,2\% artinya, 1 dari 10 bayi di Indonesia yang terlahir dengan BBLR. Angka ini masih belum dapat menjadi pedoman dalam melihat kejadian BBLR yang sesungguhnya, dikarenakan mengingat angka tersebut didapatkan dari dokumen atau catatan yang dimiliki oleh anggota rumah tangga, seperti buku Kesehatan Ibu dan Anak (KIA) dan Kartu Menuju Sehat (KMS). Sedangkan jumlah bayi yang tidak memiliki catatan BBL, jauh lebih banyak. Hal ini berarti kemungkinan bayi yang terlahir dengan BBLR jumlahnya masih jauh lebih banyak lagi.

Bayi preterm adalah bayi yang terlahir dengan usia kehamilan kurang dari 37 minggu dan dengan berat lahir kurang dari 2500 gram (Manuaba, Ida, B. G, dkk. 2007). Adapun etiologi atau penyebab persalinan prematur dapat dibagi menjadi dua kelompok, yaitu penyebab yang dikarenakan faktor fisiologis dan non fisiologis. Adapun predisposisi dari persalinan preterm yaitu: adanya riwayat persalinan preterm masa lalu, kelainan pada amnion, infeksi saluran kemih, hamil kembar, gangguan uterus, faktor biological, adanya riwayat perdarahan, ibu yang mengalami hipereklapmsia dan riwayat diabetes gestasional, AKDR masih didalam rahim, penyakit resus, kematian fetus, sosial ekonomi, tekanan psikologis dan kebudayaan yang dianut (Manuaba, Ida, B.G, dkk. 2007).

Perawatan pada bayi preterm yang terlahir di Rumah Sakit adalah dengan metode perawatan dengan penggunaan inkubator. Hal tersebut bertujuan untuk menghemat energi pada bayi preterm, sehingga energi dapat digunakan bayi preterm untuk masa pertumbuhan dan perkembangan bayi tersebut (Manuaba, Ida, B.G, dkk. 2007). Penatalaksanaan perawatan pada neonatus dengan preterm atau BBLR sangat perlu mendapat dukungan dari berbagai pihak, salah satu caranya yaitu dengan meningkatkan pengetahuan yang benar pada ibu dan keluarga atau dapat memberikan sentuhan 
terapeutik dengan konsep family center care $(F C C)$, sehingga pengetahuan ini dapat membantu ibu terhadap perawatan yang berkualitas dan tidak menimbulkan cedera pada bayi preterm atau BBLR. Dalam hal ini, penatalaksanaan perawatan pada bayi dapat dilakukan oleh seorang ibu ataupun ayah dengan cara mempertahankan suhu dan kehangatan bayi BBLR di rumah, selalu memberikan ASI kepada bayi BBLR di rumah dan berusaha mencegah terjadinya infeksi bayi pada BBLR (Girsang, 2009).

Bayi terlahir hidup dengan BBLR, akan banyak menjalani perawatan di unit perawatan intensif, pada masa perawatannya peran keluarga menjadi sangat terbatas hal ini dikarenakan ruang perawatan seperti NICU dengan pelayanan keperawatan yang lebih ekstra akan membuat orangtua menjadi dibatasi sehingga akan muncul komunikasi yang kurang efektif antara bayi dan orangtuanya, serta keluarga dengan perawat menjadi terbatas. Perawatan bayi BBLR di ruang intensif akan berdampak yang sangat bermakana bagi orang tua seperti rasa takut, rasa bersalah, stres dan cemas akan kondisi bayinya (Wong, 2009). Apalagi pada kondisi anak yang dalam perawatannya menjadi kritis sehingga akan muncul rasa takut kehilangan anak tersebut. Perasaan stres pada orang tua tidak boleh diabaikan oleh perawat hal ini dikarenakan, apabila orang tua merasa stres, bisa berdampak pada orang tua tersebut, karena keluarga atau ibu tidak dapat fokus dalam merawat anaknya (Wong, 2009). Selain itu, adanya komunikasi yang kurang antara petugas kesehatan dengan orang tua dapat memicu timblnya stres orang tua bayi BBLR.

Selaras dengan pernyataan menurut Suradi, R (2010) yang menyatakan bahwa, perawatan anak preterm dirumah sakit akan beresiko menimbulkan kesalahpahaman antara orangtua dan perawat dalam mencerna proses informasi yang diberikan oleh perawat, jika informed consent yang diberikan tidak sesuai SOP, kondisi seperti ini akan membuat anak menjadi stres begitupula orangtuanya. Oleh karena itu, selain teknik komunikasi pada anak, perawat juga harus memperhatikan bagaimana cara yang tepat dalam berkomunikasi dengan orangtua. Hal ini berguna untuk mengurangi stres yang dialami orang tua anak tersebut. Adapun menurut Friedman (1998) dalam Sitohang, H. M (2009) yang menyatakan bahwa salah satu faktor utama yang dapat melahirkan pola-pola komunikasi yang tidak berfungsi dengan menimbulkan munculnya perasaan harga diri yang rendah dari keluarga maupun anggota keluarga, khususnya orangtua adalah adanya pemusatan pada diri sendiri, perlu persetujuan total, dan kurang berempati disaat pengambilan keputusan perawatan keluarga yang sakit.

Para ibu yang memiliki bayi preterm akan mengalami perasaan sedih, cemas, duka, perasaan bersalah, pasrah, takut, dan khawatir saat melihat kondisi bayinya pertama kali (Sitohang, 2009). Emosi yang paling sering muncul adalah ketegangan berkepanjangan, perasaan kecewa, gagal dan depresi pada awal saat melahirkan bayi preterm (Lindberg, Ohrling, 2008; Nurhayati 2011). Beberapa hasil penelitian tentang pengalaman ibu dengan kelahiran bayi preterm menunjukkan bahwa memiliki bayi preterm yang dirawat diinkubator merupakan peristiwa dalam hidup yang membuat fluktuasi emosi khususnya ibu menjadi labil seperti perasaan cemas, sedih, ketidakyakinan, putus asa dan stres yang tidak menentu (Shanmugam, Valliammal. 2015).

Adanya ketidakpercayaaan diri ibu terhadap perawatan bayinya setelah kepulangan dari rumah sakit, dapat menjadikan ibu bertambah stres dan berdampak pada permasalahan yang cukup panjang seperti: ketidakberdayaan, ketidakmampuan merawat, dan kesulitan memegang bayinya (Monintja, 1997; Root, Jane 1998 dalam Deswita, Besral, Yeni Rustina, 2015). Hal yang sama juga dinyatakan oleh Guillaume, 
S., Natacha, et al (2013) yang menyatakan bahwa, setiap orang tua yang memiliki bayi preterm sangat membutuhkan support sistem yang adekuat baik dari dalam keluarga maupun lingkungan diluar keluarga, edukasi berupa pengetahuan cara perawatan bayi preterm yang tepat dan benar, sangat dibutuhkan agar mereka berpartisipasi dengan yakin dan penuh rasa percaya diri dalam perawatan bayi mereka yang sakit. Untuk mencapai tumbuh kembang yang optimal (Bobak, Jensen \& Lowdermilk, 2004).

Minimnya informasi yang diterima orang tua tentang tumbuh kembang bayi preterm dan perawatannya dapat mengakibatkan perasaan khawatir, takut dan cemas yang berlarut sehingga berdampak pada ibu kurang dalam berpartisipasi perawatan bayi preterm tersebut (Solfiani, E.T, Monalisa S \& Evelyn Hemme.T. 2016). Dalam hal ini ibu sangat membutuhkan suport dari berbagai elemen untuk meminimalisir kondisi yang terburuk dalam perawatan bayi pretermnya (Danerek, Dykes, 2006). Orangtua khususnya Ibu diupayakan dapat melewati masa sulitnya dalam menghadapi kelahiran pretem, untuk itulah dukungan dari semua pihak utamanya petugas pelayanan kesehatan maupun keperawatan harus bersinergi dengan baik dalam berkomunikasi dengan ibu, suami, keluarga, dan group pendukung yang senasib terkait masalah yang dihadapi (Laviana. N. L, 2016).

Hasil penelitian yang berjudul "Pengalaman melahirkan bayi prematur dari perspektif ibu di negara Sweden Utara yang dilakukan oleh Lindberg, Ohrling (2008) menguatkan penelitian ini. hasilnya menyatakan bahwa ibu yang melahirkan anak preterm ataupun BBLR, tidak siap dalam mengasuh dan merawat bayi yang lahir preterm dan mereka mengalami kesulitan menjadi seorang ibu pada masa awal paska melahirkan. Hal tersebut dikarenakan Ibu mengalami perasaan kecemasan dengan adanya perawatan yang terpisah dari bayinya.

Banyak solusi yang ditawarkan dalam penatalaksanaan BBLR, adapaun salah satu bentuk solusi yang cukup efektif ditawarkan untuk mengatasi rasa kekhawatiran dan kecemasan ibu atas masalah yang ia hadapi dalam perawatan anak dengan BBLR atau preterm adalah dengan perawatan metode kanguru (PMK), beberapa hasil penelitian mengenai PMK ini telah dilakukan di Indonesia. Salah satu penelitian pada tahun 2010 yang telah dilakukan di Surakarta oleh Wahyuni dalam (Solfiani, E.T, Monalisa S \& Evelyn Hemme. T 2016) yaitu menyatakan dengan membandingkan lama perawatan metode kangguru 4 (empat) jam dengan 2 (dua) jam per hari. Hasil yang didapatkan bahwa perlengketan selama 4 (empat) jam lebih efektif terhadap peningkatan berat badan bayi, dalam penelitian tersebut wahyuni merekomendasikan untuk melakukan penelitian perawatan metode kanguru selama lebih dari 4 (empat) jam (Akhtar, K., Haque, M., \& Khatoon, S, 2013).

Hasil survei dalam pengambilan data awal tanggal 10 Maret tahun 2017, data yang didapat dari buku registrasi diruang NICU RSUD. Dr. M. Yunus Bengkulu, didapatkan angka kelahiran bayi preterm terjadi penurunan dari tahun 2014-2016. Di tahun 2014 terdapat 198 kasus, di tahun 2015 terdapat 58 kasus, dan tahun 2016 terdapat 47 kasus bayi preterm dengan 15 kelahiran dari bayi preterm yang dinyatakan pulang setelah melakukan perawatan inkubator dan kembali ke rumah sakit sudah dalam kondisi yang kritis dan akhirnya meninggal. Kelahiran bayi preterm tersebut dengan masa gestasi rerata 32-36 minggu (bayi preterm sedang), 28-31 minggu (bayi sangat prematur) dan $\leq 27$ minggu (bayi amat sangat prematur) dan rerata hari rawatnya di dalam inkubator lebih kurang 0-40 hari rawat.

Berdasarkan studi pendahuluan yang dilakukan oleh peneliti kepada partisipan yang memiliki bayi preterm, menceritakan pengalaman pertama kali ketika mengetahui 
bahwa bayinya preterm seperti ungkapan Ny. P yang menyatakan "keadaan terkejut, syok dan panik, menangis dan bingung", karena seluruh badan anaknya berwarna biru, dan susah bernafas, ibu pikir anaknya tidak akan selamat.

Berbeda pada pernyataan partisipan ke 2 "Ny. T menyatakan kecemasannya semakin tinggi ketika tidak mengetahui keadaan anaknya setelah persalinan selesai, karena pihak keluarga tidak memberikan izin kepada petugas medis untuk memberi informasi kepada klien, jika anaknya lahir dengan keadaan berat badan kurang dari 2500 gr. dan setelah Ny.T mengetahui keadaan bayinya muncul perasaan duka, sakit, perasaan marah dan syok melihat keadaan anaknya dengan tubuh yang kecil. ia tidak mau berbicara dengan semua anggota keluarga dirumahnya selama 2 minggu. dan kurang berpartisipasi dalam merawat anaknya selama 18 hari".

Berbeda halnya dengan tiga ibu lainnya yang mengetahui perawatan bayi BBLR secara singkat dari seorang perawat. Selain itu dilakukan wawancara kepada 3 (tiga) ibu yang melakukan perawatan bayi BBLR di rumah. satu bayi mereka mengalami hipotermi karena mereka merawat bayinya sama seperti bayi normal yaitu mulai dimandikan dan kurang memperhatikan kehangatan bayi. Satu lagi bayinya mengalami muntah karena tersedak, satu lagi bayi lainnya mengalami penurunan berat badan selama di rawat di rumah, hal itu terjadi karena ASI ibu tidak keluar sehingga diberikan susu formula, sehingga bayi tersebut menjadi tidak suka minum ASI.

\section{METODE PENELITIAN}

Jenis penelitian yang digunakan adalah penelitian kualitatif dengan pendekatan fenomenologi. Fenomena yang diteliti adalah pengalaman ibu dalam merawat bayi preterm yang pernah dirawat di ruang Neonatus Intensive Care UNIT (NICU) di RS. Dr. M. Yunus Bengkulu. Instrumen dalam penelitian ini adalah peneliti sendiri. Validasi penelitian dilakukan dengan wawancara secara mendalam dengan informan yang sesuai dengan kriteria penelitian. Alat penelitian lain yang digunakan adalah alat tulis, mp4 player, Hp dan pedoman wawancara.

Populasi pada penelitian ini adalah para ibu yang memenuhi kriteria insklusi yaitu: pertama kali melahirkan bayi preterm, memiliki bayi preterm yang pernah menjalani perawatan inkubator selama 50 hari dan bersedia menjadi informan dalam penelitian ini. berdasarkan yang memiliki bayi preterm yang pernah di rawat di ruang neonatus intensive care unit (NICU) di RS. Dr. M. Yunus Bengkulu. sampel dalam penelitian ini diambil dengan menggunakan teknik purposive sampling yaitu memilih beberapa informan sesuai dengan kriteria-kriteria. Setelah dilaksanakannya penelitian, didapat lima informan sangat berpartisipasi dalam penelitian ini.

Pengambilan data pada informan dilaksanakan dengan menggunakan teknik wawancara terstruktur dan mendalam (in-depth interview) dan dibantu dengan penggunaan pedoman wawancara semi struktur yang berisi pertanyaan terbuka terkait tujuan penelitian yang akan dicapai. Wawancara dilakukan sekitar 45-60 menit sesuai dengan tempat dan waktu yang telah disepakati bersama informan sebelumnya. Selanjutnya informan bersedia menandatangani lembar persetujuan untuk berpartisipasi dalam penelitian ini. Setelah terkumpul data, data dianalisis dengan menggunakan metode collaizi yaitu suatu metode yang digunakan oleh peneliti yang melibatkan hasil observasi dan analisis perilaku individu dalam kesehariannya untuk menguji hasil pengalaman yang tidak bisa diungkapkan dengan kata-kata atau secara verbal. (Creswell. J.W, 2012). Hasil wawancara direkam langsung dengan menggunakan mp4 player. Validasi data langsung dilakukan oleh peneliti bila ada yang informasi yang 
kurang jelas dari jawaban masing-masing informan. Pengambilan gambar juga dilakukan oleh peneliti untuk pendokumentasian yang dilakukan dengan menggunakan HP dan pengambilan data dihentikan apabila sudah tidak ada lagi data baru yang didapat atau data telah mencapai saturasi.

\section{HASIL PENELITIAN}

Informan dalam penelitian ini berjumlah 5 (lima) orang ibu, dan yang pertama kali memiliki bayi preterm yang dirawat di ruang NICU dengan perawatan paling lama 50 hari. Peneliti melakukan proses analisis data dengan menggunakan metode collaizi dari data yang dihasilkan oleh peneliti dari hasil catatan lapangan dan selanjutnya peneliti memberikan kode agar sumber datanya mudah ditelusuri. Dalam mengumpulkan dan membuat kata kunci peneliti berupaya menemukan tema-tema yang berasal dari data, kemudian peneliti mengkoding data tersebut.

Dari hasil temuan lapangan oleh peneliti, telah mengidentifikasi ada 6 (enam) tema yang dihasilkan. Kategori tema tersebut terdaftar sebagai berikut :

Tabel. 1

Kategori dan Tema

\begin{tabular}{cll}
\hline No & \multicolumn{1}{c}{ Kategori } & \multicolumn{1}{c}{ Tema } \\
\hline 1 & Pendapat tentang bayi preterm & Gambaran dan karakteristik bayi Preterm \\
2 & Faktor-faktor terjadinya kelahiran preterm & Etiologi atau penyebab kelahiran Preterm \\
3 & Pengetahuan positif dan negatif & Kemampuan ibu merawat bayi Preterm \\
4 & Support internal dan eksternal & Bentuk dukungan yang diperoleh ibu dalam \\
& & merawat bayi preterm dirumah \\
5 & Perasaan bersalah Stress dan Cemas & Reaksi ibu selama perawatan bayi preterm \\
6 & Mekanisme koping : adaptif dan maladaftif & $\begin{array}{l}\text { Mekanisme koping diri ibu selama merawat } \\
\text { bayi preterm }\end{array}$ \\
\hline
\end{tabular}

Adapun 6 tema yang didapat adalah : 1) Gambaran Karakteristik Bayi Preterm dari Pengertian Preterm atau Berat Bayi Lahir Rendah ;

"Bayinya kecil sekali dek, dan beratnya kurang dari 2 kilo kalo nga salah"... (P1).

"Berat Bayinya kurang dari 2 kilo mbak dan lahir kurang dari 9 bulan...." (P2).

"Ya..badannya sangat kecil mbak, kurang bulan juga mbak...." (P3)

"Badannya itu mbak kecil dan bisa dipegang pake tangan satu mbak ..ehmm beratnya kira-kira kurang dari 2 kilo mbak...." (P4)

"Beratnya kurang dari 2,5 kilogram, dan harus dirawat dulu diinkubator ya..."(P5)

Saturasi data : dari lima partisipan, semua menjawab tentang karakteristik bayi preterm dari berat badannya yaitu : berat badan bayi lahir kurang dari 2,5 kg.

Etiologi atau Penyebab Kelahiran Bayi Preterm ;"waktu hamil saya mual muntah terus sampe 6 bulan, badannya kurus sekali, kata dokter saya kekurangan nutrisi. Jadi lahiranny kurang bulan ya...."(P1)

"Tidak nafsu makan, muntah terus, kata dokter saya kena hiperemesis berat..."(P2)

"waktu hamil tujuh bulan, saya mengalami perdarahan dek..."(P3)

"usia 8 bulan ketuban saya pecah, jadi melahirkan kurang bulan..."(P4)

" ga mau makan, apapun yang masuk muntah terus dek..."(P5)

Saturasi data : dari lima partisipan, semua mampu menjawab tentang penyebab kelahiran preterm pada diri ibu yaitu : 3 orang mengalami malnutrisi, 1 orang mengalami perdarahan, dan 1 orang ketuban pecah dini. Tiga hal ini menjadi penyebab 
terbesar dan kata kunci yang ibu ungkapkan sesuai dengan teori tentang etiologi kelahiran bayi preterm.

\section{Kemampuan Ibu Merawat Bayi Preterm}

"Biar tubuhnya tetap hangat bayinya digendong ditaro didada, kalo saya capek gantian dengan ayahnya. suster bilang namanya perawatan metode kangguru...."(P1)

"Sebelum pulang diajarin perawatan kangguru kalo tidak salah, yang bayinya digendong didada saya tanpa menggunakan baju..."(P2)

"Setiap pagi anaknya dijemur kurang lebih 30 menit, setelah itu bayi ditaro didada dan sering dikasih asi, kalo saya tidak mengendongnya, didekat tubuh bayi saya tarok lampu belajar dan matanya ditutupin pake kain yang beli dari perawat RS...”(P3)

"Biar badannya nga kedinginan, saya taro didada dengan perawatan metode kangguru, kalo saya lelah saya masukan anak dalam kotak dus kecil, seperti dus tempat aqua selanjutnya di bawahnya dilapisi dengan beberapa lapis kain pernel...'(P4)

"Tubuh anak saya gendong didada selama empat jam sambil saya memasak mencuci dan pernah sambil tiduran. lupa nama perawatannya apa gitu."(P5)

Saturasi data : dari lima partisipan, semua menjawab tentang kemampuan ibu dalam merawat bayi preterm : untuk menjaga stabilisasi suhu bayi, yang dapat ibu lakukan adalah melakukan perawatan kangaroo mother care (KMC), dan bayi juga sering dikasih asi.

\section{Bentuk Dukungan yang Diperoleh Ibu dalam Merawat Bayi Preterm di Rumah :}

"Suka ada bantuan makanan tambahan), seperti: kue, serelak, bubur kacang dan vitamin buat saya dari petugas puskesmas...."(P1)

"Kalo dari suami ya dukungannya sangat kuat, keluarga juga mbak, saudara-saudara juga membantu mbak, adik saya sering bantuin dirumah kalau lagi kesusahan gitu....saya seneng aja gitu mbak, apalagi kan orang-orang terdekat kita mbak...."(P2)

"Dari suami dan tetangga sekitar sering kasih dukungan, waktu masih dirumah sakit juga kasih semangat saya, gak boleh sedih terus katanya, dan gak boleh putus asa juga gitu mbak...."'(P3)

"Suami sering datang ke puskesmas bawa saya biar dapat informasi yang benar dan sering menolong gendongin juga...” (P4)

"suami saya sangat siaga dan kalo malam gantian suami yang gendongin anak saya istirahat tidur...(P5)

Saturasi data : dari lima partisipan, semua menjawab tentang bentuk dukungan yang diperoleh ibu saat merawat bayi preterm yaitu : dukungan pertama yang ibu peroleh adalah dari suaminya dan bersama suami mencari informasi terkait edukasi kesehatan tentang merawat bayi preterm dari fasilitas pelayanan terdekat yaitu puskesmas serta nutrisi pada ibu dan bayi preterm serta keluarga lainnya juga memberi dukungan dengan cara membantu ibu mengendong secara bergantian ketika ibu terlihat letih.

\section{Reaksi Ibu Selama Perawatan Bayi Preterm :}

"Sering khawatir sama anak, apalagi kalo anaknya rewel jadinya cemas dan sedih..." (P1)

"Diawal saya sering nangis dan sedih liat anak saya kecil sekali, perasaan sering ga nentu...” (P2)

"dulu saya cemas dengan masa depan anak saya, kadang saya sering menangis, bisa nga anak saya tumbuh seperti anak normal lainnya.." (P3) 
"Perasaan sering ga menentu, terkadang airmata turun aja tanpa disadarin...(P4)

"nangis dan cemas setiap hari yang saya rasakan saat itu, takutnya anak saya kenapakenapa tetiba sudah nangis aja bawannya....(P5)

Saturasi data : dari lima partisipan, semua menjawab tentang reaksi ibu selama perawatan bayinya adalah : mengalami menangis, merasa kecemasan, kehwatiran dan bersedih.

\section{Koping Diri Ibu dalam Merawat Bayi Preterm}

"Ya sabar harus sabar, lapang dada mbak, mungkin ini sudah kehendak Allah ya mbak, saya sedih tapi harus bersabar melihat keadaan anak saya waktu itu mbak tapi terkadang saya menjadi marah-marah ga jelas karena terbawa emosi..."(P1)

"meski sedih Ya gimana caranya saya harus bisa sabar meskipun kadang saya ada emosi demi dedek bayi ini, ya sabar juga dalam menghadapi kenyataan ini...."(P2)

"Namanya ibu ya mbak, saya ya cuma bisa berdoa buat anak saya supaya cepet pulih waktu itu mbak ...."(P3)

"Saya dan suami saling memberi perhatian dan suami selalu meyakinkan saya bahwa kami bisa merawat anak...(P4)

"selalu berdoa untuk kesembuhan anak, dan harus sabar, ya kalopun ada marahnya wajar toh manusia....(P5)

Saturasi data : dari lima partisipan, semua menjawab tentang koping yang ibu lakukan pada saat merawat anaknya adalah : berusaha bersikap sabar, dan saling menguatkan antara suami dan istri.

\section{PEMBAHASAN}

Dalam penelitian ini semua informan menyatakan persepsi tentang gambaran bayi preterm umumnya memiliki pengetahuan yang sama. Rerata para ibu menyampaikan bahwa berat badan bayi preterm adalah kurang normal dan kecil atau dibawah 2500 gram. Preterm ataupun BBLR seringkali sejalan dengan bayi prematur yaitu kurang dari 2500 gram (Manuaba I.B.G., Chandranita, Manuaba Fajar, 2007). Hal tersebut juga sejalan oleh teori Wong (2009) dan Bobak (2004) dalam Suradi, R. (2010) yang menyatakan bahwa, bayi yang lahir preterm memiliki ciri-ciri yaitu bayi sangat kecil, tubuh kebiruan, terlihat sesak nafas, terlihat adanya retraksi dinding dada meningkat sangat tidak berdaya, dan terlihat sangat lemah. Hal sama juga diungkapkan dari teori menurut (Perinasia, 2003) tentang bayi BBLR adalah bayi yang terlahir dengan berat badan kurang dari 2.500 gram tanpa melihat usia kehamilan. Etiologi atau Penyebab terjadinya bayi preterm atau BBLR secara umum bersifat multifaktorial. Namun, penyebab terbanyak yang mempengaruhinya adalah kelahiran prematur. Neonatus dengan kelahiran preterm akan beresiko mengalami terjadi permasalahan pada sistem tubuh, gangguan pernafasan, gangguan nutrisi dan juga mudah terkena infeksi karena daya tahan tubuh yang masih sangat lemah, kemampuan leukosit masih kurang dan pembentukan antibodi belum sempurna. Sehingga bayi BBLR sangat membutuhkan perhatian khusus dan perawatan intensif di rumah sakit terutama di ruang NICU (neonatal intensive care unit) untuk membantu mengembangkan fungsi organ tubuh bayi.

Faktor-faktor yang bisa menyebabkan bayi lahir dengan preterm, penyebab terbesarnya ada 2 yaitu dari faktor internal maupun ekseternal dari ibu itu sendiri. Kondisi psikologis yang dialami oleh ibu hamil juga menjadi penyebab ibu melahirkan secara prematur. Kondisi psikologis itu misalnya saja ibu hamil dengan kondisi dalam 
tekanan, konflik, cemas, stress, depresi dan khawatir yang berlebihan bisa membuat ibu yang sedang hamil melahirkan dengan prematur. Oleh sebab itulah, ibu yang sedang hamil selain harus pintar dalam menenangkan pikirannya, ibu juga harus mampu membuang pikiran cemas dan pikiran negatif yang dapat menurunkan atau memperburuk kesehatannya (Lee, S. C. 2008).

Faktor kesehatan dan kondisi janin yang ada didalam rahim ibu juga menjadi faktor penyebab bayi lahir prematur. Misalnya ibu yang mengalami penyakit penyerta selama kehamilannya seperti mual muntah hebat sehingga bisa menyebabkan bayi menjadi malnutrisi dan berkembang tidak optimal di dalam kandungan ibunya. Dampaknya adalah bayi tersebut dapat mengalami pertumbuhan dan perkembangan yang tidak optimal (Manuaba I.B.G., Chandranita, Manuaba Fajar 2007). Faktor penyebab bayi lahir prematur lainnya adalah ibu mengalami trauma jatuh, terpeleset ataupun terjadi benturan yang hebat dan kuat yang mengenai daerah perut ibu. Trauma tersebut juga bisa disebabkan oleh kekerasan yang ibu terima saat ibu sedang hamil seperti adanya pukulan benda keras di perut ibu yang sedang hamil. Begitupun apabila ibu hamil terjatuh dan terbentur cukup keras, hal tersebut dapat menyebabkan pendarahan yang berakhir pada kelahiran secara premature atau preterm (Lindberg, B., Ohrling, K. 2008).

Kemampuan ibu dalam merawat bayinya yang lahir prematur membutuhkan usaha yang lebih optimal dalam segi perawatannya. Hal ini dikarenakan sebagian dari bayi prematur memerlukan perawatan rumah sakit sebelum akhirnya diperbolehkan dirawat di rumah. Bayi prematur dinyatakan diperbolehkan keluar dari perawatan rumah sakit apabila telah mampu menerima asupan ASI atau susu formula tanpa bantuan pipa nasogastrik, dan terjadi kenaikan berat badan dengan stabil, serta suhu tubuh yang tetap stabil di udara biasa (Soepardam, dkk, 2010). Menurut Perinasia (2003) ibu juga harus diajarkan bagaimana cara penyimpanan ASI yang benar seperti mengajarkan bagaimana penyimpanan ASI setelah di keluarkan dari mamae ibu, lalu penyimpanan di lemari pendingin dengan pengaturan suhu $4^{0} \mathrm{C}$ selama 24 jam. Sedangkan menurut Depkes. (2016) setelah bayi pulang, ibu memiliki kewajiban dalam penjadwalan penimbangan berat badan pada bayi BBLR, secara rutin setiap hari, dan kenaikan berat badan bayi BBLR minimal 15 gram $/ \mathrm{kg} /$ hari harus tercatat dibuku KMS anak tersebut. Adapun tujuan penimbangan berat badan yang dilakukan setiap hari adalah untuk melihat apakah terjadi penambahan atau pengurangan berat badan bayi BBLR dan informasi terkait edukasi ini harus sudah ibu dapati sebelum ibu dan bayinya pulang kerumahnya.

Untuk menyusui dengan benar dibutuhkan pengetahuan dan pendidikan yang baik pula. Hal ini didukung oleh penelitian Dwi (2009) yang berjudul "Faktor - Faktor yang berhubungan dengan pemberian ASI pada ibu menyusui di Kelurahan Pangkalan Jati Kecamatan Limo Depok". Dari hasil penelitian Dwi (2009) didapatkan bahwa terdapat hubungan yang signifikan antara tingkat pengetahuan ibu dengan pemberian ASI, dan terdapat juga hubungan antara pendidikan dengan perilaku ibu dalam menyusui bayi preterm. Dari penelitian tersebut didapatkan kesimpulann yaitu: Semakin baik pengetahuan dan pendidikan seorang ibu yang memiliki bayi preterm, semakin terpenuhi pula nutrisi bayi dengan preterm atau BBLR tersebut.

Stabilitas suhu tubuh bayi dapat pula difasilitasi dengan cara pemilihan zat pemanas dengan penggunaan lampu pijar ataupun lampu sorot. Untuk lampu yang memiliki intensitas cahaya yang tinggi dengan konsumsi daya yang rendah disarankan menggunakan lampu LED, hal ini dikarenakan arus listrik yang dibutuhkan pada lampu ini sangat kecil dan konstan, sehingga lebih efisiensi dan lebih hemat dalam 
memberikan rasa hangat pada tubuh anak dengan preterm. Lampu pijar biasa memiliki tingkat intensitas yang tidak terlalu tinggi dibandingkan dengan lampu sorot, tetapi memiliki panas yang lebih tinggi, sehingga lampu jenis ini baik digunakan sebagai pemanas pada tubuh bayi, dengan catatan mata bayi sudah terlindungi secara sempurna dengan menggunakan kain dan perlu pengawasan setiap jam, sehingga semua bisa dibuat penjadwalan dalam perawatan bayi preterm. hal ini juga memerlukan dukungan yang sangat besar dari keluarga (Noor, dkk, 2010).

Masa transisi bayi premature setelah pulang dari hospitalisasi, Teridentifikasi diawal perawatan bayi preterm dirumah, rerata ibu mengalami gejala cemas, sedih, duka, kecewa, takut, khawatir, dan perasaan tidak menentu. Hasil ini sama dengan penelitian tentang pengalaman ibu yang memiliki bayi premature di negara Swedia dimana orangtua terutama ibu memiliki bayi premature merupakan sebuah pengalaman yang sangat dalam yang membuat orangtua terutama ibu mengalami duka dan kecemasan serta sedih yang mendalam (Lindberg, Ohrling, 2008). Hal tersebut selaras dengan teori yang menyatakan bahwa kecemasan merupakan bagian emosional atau psikologis ibu yang tidak menyenangkan yang ditandai jantung berdebar lebih cepat, sedih, prihatin, dan takut akan hal-hal yang belum terjadi (Atkinson, R. 2008).

Support system atau dukungan dari keluarga ataupun sahabat dekat sangat membantu ibu dalam mengatasi kecemasanya dimasa perawatan bayi preterm dirumah, disamping hal akan membantu ibu dalam mengatasi mekanisme kopingnya ke arah adaptif sehingga hal tersebut sangat diperlukan. Adapun dukungan yang dapat diberikan oleh perawat dapat. Seperti edukasi kepada keluarga berupa bantuan yang dibutuhkan ibu terkait penatalaksanaan bayi dengan preterm, serta menguatkan kepercayaan diri ibu dalam perawatan anaknya (Shanmugam, Valliammal, 2015). Hasil penelitian didapatkan informasi bahwa rerata informan dalam penelitian ini mengungkapkan bahwa selama masa sulitnya setelah pulang perawatan dari rumah sakit, suaminya banyak memberikan bantuan baik berupa tenaga maupun kasih sayang yang selalu dicurahkan kepada istri dan anaknya hal ini selaras dengan pernyataan yang menyatakan bahwa seorang suami dapat memberikan suport baik berupa sosial maupun emosional dari orang-orang yang memiliki ikatan pernikahan sebagai suami ataupun istri (Shanmugam, Valliammal, 2015).

Keluarga khususnya ibu memiliki peran penting dalam merawat dan mengasuh bayinya dengan baik. Menurut hasil penelitian yang dilakukan oleh Bang, A.T dan Bang, R.A. (2005) menyatakan bahwa perawatan ibu pada bayi BBLR sangat berdampak pada kualitas dan kwantitas pertahanan hidup BBLR dan bila ibu tidak melakukan perawatan dengan baik maka akan berdampak pada angka kejadian penurunan kesehatan dan dapat menyebabkan terjadinya infeksi, malnutrisi dan kematian pada bayi BBLR. Hasil penelitian ini juga didukung oleh pernyataan Maryuni dan Anik, (2013) yang menyatakan bahwa respon ibu terhadap permasalahan bayi BBLR sangat mempengaruhi keputusan ibu untuk melakukan perawatan terhadap bayinya dan berdampak pada proses pertumbuhan dan perkembangan BBLR, masih banyak para ibu yang belum bisa merawat bayinya dengan baik, sehingga banyak bayi BBLR yang tidak terselamatkan disebabkan karena kurangnya pengetahuan ibu tentang cara perawatan bayi BBLR dengan benar. Di penelitian ini para ibu mendapat suport sistem yang cukup baik dari suaminya ataupun orang-orang terdekat sehingga ibu mampu melewati masa ini dengan baik.

Keluarga merupakan unit yang menjadi prioritas yang harus direkomendasikan untuk meningkatkan pengetahuan sebanyak mungkin, terutama dalam mempelajari 
tentang psikologis yang dapat terjadi pada ibu dalam masa perawatan bayi preterm dan kebutuhan khusus apa saja dalam perawatan bayi preterm agar keluarga terutama ibu lebih optimal dalam berpartisipasi secara aktif untuk meningkatkan derajat kesehatan keluarga ataupun bayi preterm seperti memberikan sentuhan terapeutik salah satunya adalah dengan menggunakan Perawatan Metode Kangguru (PMK). Informasi ini dapat diperoleh keluarga dengan cara aktif dalam memanfaatkan fasilitas pelayanan kesehatan yang berada dilingkungan dekat rumahnya dengan cara aktif datang berkonsultasi dan bertanya kepada petugas kesehatan maupun rajin membaca melalui media cetak seperti majalah dan tabloid atau bisa juga googling membaca sebuah artikel terkait perwatan pada anak dengan preterm (Iqbal, et all (2007). Karena kesalahan yang sering terjadi pada orangtua adalah masih menggangap bayi dengan berat badan lahir rendah mendapatkan perlakuan yang sama dengan bayi lahir matur sehingga lebih mudah untuk mengalami hipotermi, hal tersebut dikarenakan lemak subkutan bayi dengan preterm sangat tipis sehingga mudah dipengaruhi oleh suhu lingkungan (Priya, J.J, 2004). Berbeda halnya dengan perawatan BBLR Di RS dapat menggunakan inkubator. Oleh karena itu diperlukan suatu metode praktis sebagai alternatif pengganti inkubator yang secara ekonomis cukup efesien dan efektif. Penggunaan inkubator dinilai dapat menghambat dan mengurangi kontak dini antara ibu-bayi sehingga pemberian air susu ibu (ASI) secara langsungpun menjadi kurang efektif (Suradi, 2010). Indonesia merupakan salah satu negara yang sedang berkembang yang sangat dianjurkan untuk mengadopsi metode ini, karena mengingat terbatasnya fasilitas pelayanan kesehatan, terutama di daerah pedesaan, yang tentu saja pelaksanaannya disupervisi oleh tenaga kesehatan melalui praktik homevisite atau kujungan kerumah pasien (Maryuni, Anik, 2013).

Adapun upaya-upaya yang dapat dilakukan oleh ibu dalam menjaga stabilitas suhu bayi, yaitu dengan cara mengajarkan teknik PMK yang benar. Metode ini dilakukan dengan cara, ibu dan anak melakukan kontak secara langsung antara kulit bayi dengan kulit ibu atau skin-to-skin contact, dimana ibu menggunakan suhu tubuhnya untuk menghangatkan bayi. Metode perawatan ini juga terbukti mempermudah pemberian ASI sehingga meningkatkan perlengketan dan lebih sering dalam pemberian ASI, meminimalisir terjadinya infeksi, meningkatkan stimulasi, keselamatan dan kasih sayang antara ibu dan anaknya (Department of Reproductive Health and Research World Health Organization Geneva, 2013). Pengetahuan yang harus ibu dapati lainnya adalah mengenai perawatan bayi BBLR pada aspek pencehagan terjadinya infeksi pada bayi BBLR mencakup lima hal, diantaranya adalah cara mengangkat bayi untuk menghindari injuri, mengenal tanda infeksi bayi dan mencegah infeksi, perawatan tali pusat, mengganti pakaian dan popok, menghindari pemakaian bedak yang berlebihan dan penggunaan minyak penghangat seperti minyak telon secukupnya.

Hal diatas sejalan dengan teori yang diungkapkan oleh Perinasia, (2003) yang menyatakan Perawatan Metode Kanguru (PMK) merupakan perawatan untuk bayi berat lahir rendah atau lahiran prematur dengan melakukan kontak langsung antara kulit bayi dengan kulit ibu atau skin-to-skin contact, dimana ibu menggunakan suhu tubuhnya untuk menghangatkan bayi. Pada awalnya, PMK terdiri dari 3 (tiga) komponen, yaitu : kontak kulit ke kulit (skin-to-skin contact), pemberian ASI atau breast feeding, dan dukungan terhadap ibu (support). Literatur terbaru menambahkan satu komponen lagi sehingga menjadi terdiri dari 4 komponen, yaitu: kangaroo position, kangaroo nutrition, kangaroo support and kangaroo discharge. Posisi kanguru adalah menempatkan bayi 
pada posisi tegak di dada ibunya, di antara kedua payudara ibu, dan tanpa pakaian. Bayi dibiarkan telanjang hanya mengenakan popok, kaus kaki dan topi sehingga terjadi kontak kulit bayi dan kulit ibu seluas mungkin. Posisi bayi diamankan dengan kain panjang atau pengikat lainnya atau dapat menggunakan baju kangguru yang sudah ada. Kepala bayi dipalingkan ke sisi kanan atau kiri, dengan posisi sedikit tengadah (ekstensi) dan ujung pengikat tepat berada di bawah kuping bayi (Perinasia, 2003; Laviana. N. L, 2016).

Posisi kepala seperti ini bertujuan untuk menjaga agar saluran napas tetap terbuka dan memberi peluang agar terjadi kontak mata antara ibu dan bayi. Kanguru nutrisi merupakan salah satu manfaat PMK, yaitu meningkatkan pemberian ASI secara langsung maupun dengan pemberian ASI perah. Kangaroo support merupakan bentuk bantuan secara fisik maupun emosi, baik dari tenaga kesehatan maupun keluarganya, agar ibu dapat melakukan PMK untuk bayinya. Sedangkan kangaroo discharge adalah membiasakan ibu melakukan PMK sehingga pada saat ibu pulang dengan bayi, ibu tetap dapat melakukan PMK bahkan melanjutkannya di rumah. Metode ini merupakan salah satu teknologi tepat guna yang sederhana, murah dan dapat digunakan apabila fasilitas untuk perawatan BBLR sangat terbatas (Perinasia, 2003; Sitohang, H. M, 2009).

Perawatan Metode Kanguru (PMK) dapat dilakukan dengan dua cara; 1. PMK intermiten yaitu bayi dengan penyakit atau kondisi yang berat membutuhkan perawatan intensif dan khusus di ruang rawat neonatologi, bahkan mungkin memerlukan bantuan alat. Bayi dengan kondisi ini, PMK tidak diberikan sepanjang waktu tetapi hanya dilakukan jika ibu mengunjungi bayinya yang masih berada dalam perawatan di inkubator. PMK dilakukan dengan durasi minimal satu jam, secara terus-menerus per hari. Setelah bayi lebih stabil, bayi dengan PMK intermiten dapat dipindahkan ke ruang rawat untuk menjalani PMK continue. 2. PMK continue: pada PMK continue, tandatanda vital bayi sudah dalam keadaan stabil, dan bayi sudah dapat bernapas secara alami tanpa bantuan oksigen. Kemampuan untuk minum (seperti menghisap dan menelan) bukan merupakan persyaratan utama, karena PMK sudah dapat dimulai meskipun pemberian minumnya dengan menggunakan pipa lambung.

Efek positif yang dapat terlihat dari manfaat dalam pelaksanaan PMK bagi bayi yang lahir dengan preterm atau BBLR ataupun premature yaitu rerata sangat bermanfaat dalam menurunkan secara bermakna jumlah neonatus atau bayi baru lahir yang meninggal, menghindari bayi berat lahir rendah dari kedinginan (hipotermia), menstabilkan bayi, mengurangi terjadinya infeksi, meningkatkan pertumbuhan dan perkembangan bayi, meningkatkan pemberian ASI, dan meningkatkan ikatan (bounding attachment) antara ibu dan bayi (Perinasia, 2003; Suradi, R. 2010).

Hal tersebut selaras dengan hasil penelitian Dyah, P. A, Siti. M, Rina. P, (2008) yang membuktikan keefektifan perawatan metode kanguru tidak hanya mampu menstabilkan suhu tubuh bagi bayi, akan tetapi juga mampu untuk meningkatkan berat badan bayi tersebut. Penerapan metode kanguru pada penelitian ini terbukti dapat meningkatkan berat badan bayi secara optimal. Hal ini dikarenakan selama proses PMK terutama secara kontinu sehingga pemberian ASI dapat terjadi lebih mudah prosesnya dan dapat meningkatkan asupan ASI bagi bayi preterm (Fiyana, s, fathikul, Y.S, 2014; Perinasia, 2003). 


\section{SIMPULAN}

Jenis penelitian kualitatif dengan menggunakan desain fenomenologi deskriptif yang menghasilkan 5 (lima) informan sebagai sumber data yang diperoleh selama penelitian dilapangan. Dari hasil wawancara dengan informan didapat 6 (enam) tema. Berdasarkan hasil analisis peneliti sudah mendapatkan saturasi data. Penelitian ini sudah menjawab tujuan penelitian yaitu mengeksplorasi pengalaman ibu dalam merawat bayi preterm yang pernah dirawat di ruang Neonatus Intensive Care Unit (NICU) Kota Bengkulu.

Hasil penelitian ini mengindentifikasi 6 (enam) tema yaitu :

(1) Gambaran tentang bayi preterm dan karakteristiknya, Seperti : bayinya terlihat lebih kecil, berat badan bayi kurang dari normal, rerata anaknya lahir dengan berat badan kurang dari $2 \mathrm{~kg}$, kelahiran kurang dari 9 bulan, kelahiran 7 bulan dan kurang bulan. (2) Penyebab kelahiran preterm seperti : mual-muntah hebat selama kehamilan sehingga ibu tidak nafsu makan, jatuh, trauma, terjadi pendarahan, dan letak sungsang. (3) Kemampuan ibu merawat bayi preterm di rumah seperti : perawatan metode PMK, menggunakan lampu, menggunakan botol air hangat, menggunakan dus, dijemur dengan cahaya matahari, memberikan asi, susu formula, makanan tambahan, memandikan, menyeka, imunisasi dasar. (4) Bentuk dukungan ibu dalam merawat bayi preterm seperti memberikan :makanan berupa ASI dan susu formula, mencari informasi ke pusat layanan kesehatan, adanya perhatian dan suport sistem dari suami, orangtua, dan lingkungan tentangga. (5) Koping diri ibu selama merawat bayi preterm seperti: bersikap sabar, menguatkan diri, berdoa, berpikir positif, bercerita dengan orang lain dan sempat juga diawal merasa marah, berduka, dan sering menangis (6) Reaksi ibu selama merawat bayi preterm seperti: perasaan bersalah, kekhawatiran, kesedihan, kecemasan, menjadi lebih emosional dengan cara menangis dan terkadang suka marahmarah tidak jelas.

Pengalaman ibu dalam memiliki bayi preterm, mengungkapkan respon perasaan baik (berusaha tenang dan sabar) atau negatif (marah, kecewa, berduka, menangis) pada saat paska mengetahui kondisi dan kelahiran bayi pretermnya. Walaupun demikian ibu mampu melewati perasaan tersebut, sehingga mereka mampu merawat bayinya yang dalam keadaan preterm dengan tingkat kesehatan yang cukup baik sesuai dengan tumbuh kembangnya. Terdapat pengalaman ibu yang memiliki bayi preterm mengalami masa sulit dan tidak mudah mereka alami, yaitu pada saat anaknya mengalami sakit. Ibu harus sangat ekstra dalam pelaksanaan perawatan bayinya dan harus mampu untuk melewati masa sulit dikala anak-anaknya mengalami sakit.

Hal penting yang peneliti dapat disimpulkan dalam penelitian ini adalah bahwa keluarga terutama ibu sangat berperan besar dalam menjaga dan merawat anggota keluarganya, demi mempertahankan kesehatan anaknya dan disamping itu orang terdekat sangat membantu memberikan kenyamanan dan rasa percaya diri pada ibu dalam merawat anaknya serta anak dengan preterm tidak pernah lepas dari perhatian orang tua khususnya oleh seorang ibu. 


\section{SARAN}

Direkomendasikan kepada pihak-pihak yang terkait dengan kelahiran bayi preterm adalah:

Pelayanan keperawatan tingkat puskesmas harus menjadi konselor dan advokat dari setiap pengalaman yang dialami ibu. Perawat dapat melakukan perawatan dan kunjungan kerumah pasien, maka perawat harus dibekali dengan pengetahuan yang benar tentang penyakit dan kondisi psikologis keluarga dengan anak yang lahir preterm agar orangtua lebih menjadi mengerti dalam mengambil keputusan ketika bayinya sedang rewel ataupun sakit.

Untuk orangtua terutama ibu harus mendapatkan informasi juga terkait dukungan seperti pengetahuan, semangat atau motivasi dan konseling kesehatan baik ibu dan juga anak serta kepada ibu yang memiliki bayi preterm, disamping mengoptimalkan penggunaan fasilitas pelayanan kesehatan, ibu juga disarankan untuk berkumpul bersama ibu-ibu lainnya yang memiliki bayi preterm juga, sehingga koping mekanisme ibu lebih adaptif dalam masa perawatan bayi pretermnya.

Untuk peneliti selanjutnya disarankan lebih baik meneliti lebih lanjut pengalaman ibu dalam merawat bayi preterm dengan menggunakan pendekatan Grounded theory yang lebih refleksif dan terbuka.

\section{DAFTAR PUSTAKA}

Akhtar, K., Haque, M., \& Khatoon, S. (2013). Kangaroo Mother Care:A Simple Method to Care for Low-Birth-Weight Infants in Developing Countries. Journal of Shaheed Suhrawardy Medical College, 5 (1), 49-54

Atkinson, R. (2008). Pengantar Psikologi. Jakarta: Erlangga

Balitbang Kemenkes RI. (2013). Riset Kesehatan Dasar; RISKESDAS. Jakarta: Balitbang Kemenkes RI

Bang, A. T, \& Bang, R. A. (2005). Low Birth Weight and Preterm Neonatus: Can they Managed at Home by Mother and a Trained Village Health Worker. Journal of Perinatology, S72-S81

Bobak, L \& Jensen. (2004). Buku Ajar Keperawatan Maternitas (Maternity Nursing) Edisi 4. Jakarta: EGC Kedokteran

Creswell, J.W. (2012). Educational Research Planning, Conducting and Evaluating Quantitative and Qualitative Research Fourth Edition. Bouston: Pearson; hal. 236

Danerek, M., Dykes, A. (2006). A Theoretical Model of Parent's Experiences of Threat of Preterm Birth in Sweden. International Journal of Nursing Practice, 24, 416424. (Diakses 1 Desember 2017) URL : http: //europepmc. org/ abstract/ med.pdf

Department of Reproductive Health and Research World Health Organization Geneva. (2003). Kangaroo Mother Care: A Practical Guide. (diakses tanggal 23 Oktober 2013) http://whqlibdoc.who.int/publications/2003/ 9241590351.pdf

Depkes RI. (2016). Perawatan Bayi Berat Lahir Rendah (BBLR) dengan Metode Kanguru. Jakarta: Health Technology Assessment Indonesia

Deswita, Besral, Yeni Rustina. (2015). Pengaruh Perawatan Metode Kanguru terhadap Respons psikologis Bayi Prematur. Jurnal Kesehatan Masyarakat Nasional, 5(5), April 2015

Dwi. (2009). Faktor - Faktor yang Berhubungan dengan Pemberian ASI pada Ibu Menyusui di Kelurahan Pangkalan Jati Kecamatan Limo Depok. (diakses tanggal 01 Juni 2017). URL : FK UPN. http: Downloads(Documentslpdf

Dyah, P. A, Siti. M, Rina. P. (2008). Pengaruh Penerapan Metode Kanguru dengan 
Peningkatan Berat Badan Bayi Baru Lahir Rendah (BBLR) di Rumah Sakit PKU Muhammadiyah Gombong

Fiyana, S dan Fathikul, Y.S. (2014). Pengalaman Ibu Dengan Bayi Berat Lahir Rendah (Bblr) Mengenai Pelaksanaan Perawatan Metode Kanguru (PMK) Di Rumah. Jurnal Keperawatan UNDIP, 3(1), 320-332

Girsang, M. (2009). Pola Perawatan Bayi Berat Lahir Rendah di Rumah Sakit dan di Rumah dan Hal-Hal yang Mempengaruhinya. (Diakses 3 Maret 2017). FIK UI. Thesis

Guillaume, S., Natacha. (2013). Parent's Expectations of Staff in the Early Bonding Process with Their Premature Babies in the Intensive Care Setting: A Qualitative Multicenter Study with 60 Parents. BMC Pediatrics, 13(18), 1-9. (diakses 12 November, 2016. URL: http://www.biomedcentral.com/ 1471-2431/13/ 18. Proquest database

Iqbal. (2007). Promosi Kesehatan: Sebuah Pengantar Proses Belajar Mengajar dalam Pendidikan. Yogyakarta: Graha Ilmu

Jackson, K, Ternestedt, B.M.,\& Schollin, J. (2010). From Alienation to Familuarity: Experiences of Mothers and Fathers of Preterm Infants. Journal of Advanced Nursing, 43(2), 120-129

Laviana. N. L. (2016). Peningkatan Bonding Attachment Bayi Prematur dengan Melibatkan Orang Tua dalam Asuhan Keperawatan sebagai Bentuk Tindakan Caring yang Dilakukan Perawat. Jurnal Care, 4(1), 1-7

Lee, S. C. (2008). Taiwanese Women's Experiences of Becoming a Mother to a VeryLow-Birth-Weight Preterm Infant: A Grounded Theory study. International Journal of nursing Studies, 46, 326-327

Lindberg \& Ohrling, (2008). Experiences of Having a Prematurely Born Infant from the Perspective of Mothers in Northern Sweden. International Journal of Circumpolar Health, 67(5), 461-471

Manuaba I.B.G., Chandranita, \& Manuaba. F (2007). Pengantar Kuliah Obstetri. Jakarta: EGC

Maryuni \& Anik. (2013). Asuhan Bayi dengan Berat Badan Lahir Rendah. Jakarta: CV.Trans Info Media

Noor \& Oyas. (2010). Analisis Distribusi Temperatur dan Aliran Udara pada Bayi dengan Variasi Tipe Dinding dan Overhead Screen. Skripsi. (Di akses pada 20 November 2017). URL: http://ojs. amikom. ac.id/index. php/ semnas teknomedia /article/viewFile/852/816

Perinasia. (2003). Perawatan Bayi dengan Berat Badan Lahir Rendah dengan Perawatan Metode Kanguru. Jakarta: Perinasia

Priya, J. J. (2004). Kangaroo Care For Low Birth Weight Babies. Nursing Journal of India. (Diakses tanggal 10 juli 2017). URL : https:// search. proquest. com/ openurl/handler/.pdf

Shanmugam, V. (2015). Stress and Coping Strategies among Mothers of Neonates, Admitted in Neonatal Intensive Care Unit. Asian Journal of Nursing Education and Research 5(3). (Diakses 20 Oktober 2017). URL:http: //searh.proquest.com/openview/7af9910fd59b572e012e8d6eadd26cf2/1.pqorigsit te $=$ gscholar

Sitohang, H. M. (2009). Pengalaman Ibu Memiliki Bayi Prematur di Rumah Sakit. dr Pringadi Medan. (Diakses pada 20 Oktober 2017). URL: http: //Repository. Usu .ac.id/ 
Soepardam. (2010). Panduan Perawatan Bayi Sakit. Jakarta: Puspa Swara

Solfiani,E.T, Monalisa S, Evelyn HemmeT. (2016). Pengalaman Ibu dalam Pelaksanaan Perawatan Metode Kangguru di Rumah terhadap Bayi Berat Badan Lahir Rendah di Wilayah Kerja Puskesmas Parongpong Kabupaten Bandung Barat. Jurnal Skolastik Keperawatan Advent, 2(1), 103-110. (Diakses 20 Juli 2017). URL : Jurnal.unai.edu/index.php/jsk/article/view/244.pdf

Suradi, R. (2010). Perawatan Metode Kanguru sebagai Pengganti Inkubator untuk Bayi Berat Lahir Rendah. Seminar Perawatan Kanguru di Rumah Sakit. Tantangan dan harapan. Jakarta: Perinasia DKI Jakarta

WHO. (2014). Comprehensive Implementation Plan on Maternal, Infant and Young Child Nutrition. (Diakses pada 23 Januari 2017). URL : http ://etd. respiratory. ugm.ac.id

Wong, D. L., Eaton. (2009). Buku Ajar Keperawatan Pediatrik. Edisi 6 vol.1. Jakarta: ECG 